\title{
Deepening teachers' engagement to improve learners' performance in modular learning through OCEANS 13 program
}

Aprofundando o envolvimento dos professores para melhorar o desempenho dos alunos na aprendizagem modular por meio do programa OCEANS 13

Profundizar el compromiso de los maestros para mejorar el desempeño de los alumnos en el aprendizaje modular a través del programa OCEANS 13

Angelie M. C. Gomez- PhD angelie.casan@gmail.com Federico Yap National High School, Astorga, Sta. Cruz, Davao del Sur https://orcid.org/0000-0002-7894-8577

Emma C. Ceballo, MaeD, MPsy, RPm, RGC emma.ceballo002@deped.gov.ph Federico Yap National High School, Astorga, Sta. Cruz, Davao del Sur https://orcid.org/0000-0001-9601-5554

\begin{abstract}
The outbreak of COVID- 19 challenged the education sector to continue the delivery of quality and accessible education. Most teachers in the Senior High School were concerned about the lack of motivation on the part of the learners to submit the modules given to them as well as the activity sheets during remediation resulting to poor academic performance. Hence, this study aimed to improve learners' performance in modular learning by deepening teachers' engagement through the OCEANS 13 Program. This program had 3 phases. The first phase was AGAK (Ang Gitinguha Atong Kab-uton) or (Reach our Dreams) which was a Parent-Teacher-Learner Consultation, the second phase was Intensified Home Visitation (IHV) and the third phase was HBO (Hawak-kamay with the Brgy. Officials) or (hand-in-hand with community officials) which was a partnership of the school and community officials. These interventions were conducted to the 20 Grade 11 learners who were at risk of failing during the onset of COVID-19, School Year 2020-2021. The conduct of the 2 phases of this program has significantly improved the learners' performance as it is evident in the learners' status at the end of the semester with a $100 \%$ of the students who passed in all subject areas. The $3^{\text {rd }}$ phase was not conducted anymore. Results from the Pre and Post-Intervention Surveys to the 73 learners with grades 75-79 about their teachers' engagement revealed that the difference between the two means is significant even at the 0.01 level $(p=0.000345, p<.01)$. Hence, this signifies that OCEANS 13 , is very effective not just in the improvement of the learners' performance but also it changed significantly the perception of the students on the treatment of their teachers toward them. Based from the results of this study, we recommend to continue this program.
\end{abstract}

Keywords: Teachers' engagement, teachers' communication, Home Visitation

\section{RESUMEN}

El brote de COVID-19 desafió al sector educativo a continuar brindando una educación accesible y de calidad. La mayoría de los docentes de la Escuela Secundaria Superior estaban preocupados por la falta de motivación por parte de los alumnos para presentar los módulos que se les dieron, así como las hojas de actividades durante la remediación, lo que resultó en un rendimiento académico deficiente. Por lo tanto, este estudio tuvo como objetivo mejorar el desempeño de los alumnos en el aprendizaje modular al profundizar la participación de los maestros a través del Programa OCEANS 13. Este programa tuvo 3 fases. La primera fase fue AGAK (Ang Gitinguha Atong Kab-uton) o (Alcanzar nuestros sueños) que fue una Consulta de padres, maestros y alumnos, la segunda fase fue Visitas domiciliarias intensificadas (IHV) y la tercera fase fue HBO (Hawak-kamay con los funcionarios de Brgy.) o (de la mano con los funcionarios de la comunidad) que fue una asociación de la escuela y los funcionarios de la comunidad. Estas intervenciones se realizaron a los 20 alumnos de $11 .^{\circ}$ grado que corrían el riesgo de reprobar durante el inicio de la COVID-19, año escolar 2020-2021. La realización de las 2 fases de este programa ha mejorado significativamente el rendimiento de los alumnos, como es evidente en el estado de los alumnos al final del semestre con un $100 \%$ de alumnos que aprobaron en todas las materias. La tercera fase ya no se llevó a cabo. Los resultados de las Encuestas previas y posteriores a la intervención a los 73 alumnos con grados 75-79 sobre el compromiso de sus maestros revelaron que la diferencia entre las dos medias es significativa incluso en el nivel $0.01(\mathrm{p}=0.000345, \mathrm{p}<.01)$. Por lo 
tanto, esto significa que OCEANS 13 es muy efectivo no solo en la mejora del desempeño de los alumnos, sino que también cambió significativamente la percepción de los estudiantes sobre el trato de sus maestros hacia ellos. Con base en los resultados de este estudio, recomendamos continuar con este programa.

Palabras clave: Compromiso de los docentes, comunicación de los docentes, Visita domiciliaria

\section{RESUMO}

O surto de COVID-19 desafiou o setor educacional a continuar a oferecer educação de qualidade e acessível. A maioria dos professores do Ensino Médio se preocupou com a falta de motivação por parte dos alunos para entregar os módulos que lhes foram ministrados, bem como as fichas de atividades durante a remediação, resultando em baixo desempenho acadêmico. Assim, este estudo teve como objetivo melhorar o desempenho dos alunos na aprendizagem modular, aprofundando o envolvimento dos professores por meio do Programa OCEANS 13. Este programa teve 3 fases. A primeira fase foi AGAK (Ang Gitinguha Atong Kab-uton) ou (Reach our Dreams) que foi uma Consulta Pai-ProfessorAluno, a segunda fase foi Intensified Home Visitation (IHV) e a terceira fase foi HBO (Hawak-kamay com os funcionários do Brgy.) ou (de mãos dadas com os funcionários da comunidade) que foi uma parceria da escola e funcionários da comunidade. Essas intervenções foram realizadas para os alunos do $20^{\circ}$ ano do $11^{\circ}$ ano que corriam risco de reprovação durante o início do COVID-19, ano letivo 2020-2021. A condução das 2 fases deste programa melhorou significativamente o desempenho dos alunos, como é evidente no estado dos alunos no final do semestre com $100 \%$ dos alunos aprovados em todas as disciplinas. A $3^{\mathrm{a}}$ fase não foi mais realizada. Os resultados das Pesquisas Pré e Pós-Intervenção aos 73 alunos com notas de 75 a 79 anos sobre o envolvimento de seus professores revelaram que a diferença entre as duas médias é significativa mesmo no nível $0,01(\mathrm{p}=0,000345, \mathrm{p}<0,01)$. Portanto, isso significa que OCEANS 13, é muito eficaz não apenas na melhoria do desempenho dos alunos, mas também mudou significativamente a percepção dos alunos sobre o tratamento de seus professores em relação a eles. Com base nos resultados deste estudo, recomendamos a continuidade deste programa.

Palavras-chave: Engajamento de professores, comunicação de professores, visita domiciliar

\section{INTRODUCTION}

The outbreak of COVID- 19 challenged the education sector to continue the delivery of quality and accessible education. Since October 2020, the school utilized modular instruction for the learners. The school implemented a schedule on the distribution and retrieval of modules.

However, it was experienced by most teachers in the Senior High School that there were learners who did not submit the modules and activity sheets on their schedule. It was also observed that some learners returned the modules and activity sheets without answers. In this case, the learners were given the chance to answer the module again or they were given another remedial activity to work on. Yet, the result is the same. They did not answer the remedial activities given to them.

The learners were asked on the reasons why they returned the modules unanswered and the most common reasons were: they did not understand the instructions in the modules, they were not used to working alone without the teachers' guidance, and the questions in the module are hard for them to answer on their own.

"Mahirap sagutan ang ibang mga activities. I am surprised and shocked at first. (The module is very difficult. I am surprised and shocked at first.") [4600:4678]

"Ma'am, it was difficult to be honest. Without the usual face to face explanations and interactions from both the teachers and my classmates I had a hard time learning the concepts on my own." [639:965]

In addition, the learners expressed the need for a teacher and student communication. However, they were ashamed to communicate with their teachers because they felt that they had an incorrect understanding of the instructions.

"Natatakot akong baka mali ang aking pagkakaintindi, na baka iba ang aking naintindihan sa totoong ipinapahiwatig nito. Natatakot akong makagawa ng mali, dahil nga baka mali ang aking pagkakaintindi. Nahihiya akong makagawa ng mali, dahil hindi ako kasing talino ng iba, na mas madaling makaintindi." [I am afraid that maybe I did not understand the instructions/meaning. I am afraid to make mistakes based from 
misunderstanding (of the module). I am ashamed to make mistakes because I am not as intelligent as the other students who can understand easily.] [339:637]

This quandary alarmed the teachers because in the modular instruction, it is expected that the learners will answer all the activities given to them. This will be the basis of their grades for every quarter. Hence, we proposed an intervention to improve learners' performance especially to those learners who are at risk of failing. It is the teachers' responsibility and accountability that no learner should be left behind in this pandemic.

Communication between the teacher and learners is a tool to achieve academic success. Asrar et al. (2018) revealed in their study that effective communication has an important role in the learners' education as well as in building the character and values. Effective and quality teaching requires love, affection, sincerity, obligation, responsibility and dedication from the teacher. These factors can be manifested by the teachers through communicating with the learners. Thus, the competence and approaches of teachers' communication have an impact to the performance of the learners.

Volume of studies have been conducted regarding teacher-students communication. These studies indicated the influence of teacher- student relationship to students' behavior towards learning as well as their academic achievement. Baruch, Hershkovitz \& P. Ang (2015) advocated a positive relation between teachers and students. The learners' academic success is directly related to the effective communication of the teacher. Effective communication can help the teachers to develop good relation with the students (Khan et al., 2017 and Richmond, 1990).

In addition to effective communication and positive teacher- student relationship, home visitation has a great influence to the students' performance and commitment in their studies. Several researches revealed the significance to conduct home visitation and create strong partnerships with parents. These are considered big efforts to reach out learners who met problems in the school and these are established in the outcome of the study of Henderson et al., (2007).

If there is a stronger partnership between families, communities and schools, learners' achievement in the school will be increased. Garcia (2014) also supported this idea that conducting meetings and home visits are opportunities of parents to support their children. Both parents and teachers should be involved in their child's education. Garcia's (2014) study also revealed the importance of communication. The parents and teachers articulated that mutual communication exchange is essential to the students' learning.

To deepen teachers' engagement, we established and maintained constant communication with the learners who are at risk of failing. Inspired by a Hollywood Film, we named the program OCEANS 13. It stands for Operation Connect, Encourage and Nurture Students. Number 13 is the number of teachers including the Assistant Principal in the Senior High School who collaboratively helped in the implementation of the program.

OCEANS 13 had 3 phases; the first phase was AGAK (Ang Gitinguha Atong Kab-uton), the second phase was Intensified Home Visitation (IHV) and the third phase was HBO (Hawak-kamay with the Brgy. Officials).

\section{Statement of the Problem}

This study sought to answer the question "How effectively does the OCEANS 13 Program improve learners' performance?"

\section{THEORETICAL FOUNDATION}

This study was anchored to the ethics of caring of the school and the teachers by Noddings (2006). Care is basic aspect in life and everyone wants to be cared for. A teacher to become effective has to utilize both cognition and emotion because it will facilitate maximum learning. The learners as they spent time studying is an entirely an emotional experience.

In addition, Noddings (2006) emhasized home as a site for educational encounters. The school is the learners' home. Hence, learners should be in a school which has attention and love. As used in the study, caring was evident through the deeper engagement of teachers to the learners.

In the study of Lee \& Yuen (2019), one of the roles of the teachers is being care-givers and advicegivers. Hence, this is possible of teachers and students have established relationship or engagement.

Reeve \& Shin (2020) also disclosed that teachers must adopt greater autonomy support to the learners. If given such, students also express their interest in the school. 
Lasty, Paschal \& Mkulu (2021) revealed in their study that teacher-student's relationship is a crucial determinant and catalyst to academic performance in the schools of Tanzania. They recommended that teachers must introduce close relationships with their students.

\section{METHODOLOGICAL PROCEDURES}

This chapter presents the design, sampling method, instrument, procedures and data analysis of the study.

\subsection{Research Design}

This research is quantitative in design and descriptive in presentation and analysis of data.

\subsection{Respondents and Sampling}

The sampling procedure was purposive sampling. The purposive sampling technique, also called judgment sampling, is the deliberate choice of a participant due to the qualities the participant possesses (Etikan, I., Musa, S. A., \& Alkassim, R. S., 2016). It is a nonrandom technique that does not need underlying theories or a set number of participants. Simply put, we decided on what needs to be known and sets out to find students who can and are willing to provide the information by virtue of knowledge or experience.

There were 73 Grade 11 learners with grades 75-79 who answered the Pre- and Post- Intervention Survey. There were 20 learners who received the intervention. These learners were at risk of failing in all their subjects.

\subsection{Research Instrument}

The researcher utilized researcher- made Questionnaire on Teachers' Engagement which was validated by experts in the field of education. For the qualitative data, the researchers employed virtual interview or limited face-to-face interview.

\subsection{Data Gathering Procedure}

In the conduct of the study, we considered and gave priority on the ethical issues and addressed the study protocol in conducting the research because the study participants were adolescents. We made sure that participation of the respondents and key informants was entirely voluntary. To ensure privacy and confidentiality, the learners did not write their names in the survey and interview. Further, the researcher kept the records of the study and did not disclose to anyone. Lastly, the researcher obtained Informed Consent. We disclosed the entire purpose, the process of the research study as well as the potential benefits for them.

As to the whole process of this research, we secured the permission from the Sta. Cruz North District Research Committee to conduct the study before asking the approval of the School Principal to implement the intervention program in the school level. After securing both approvals, we finalized the list of research participants and asked them to sign the Informed Consent Form. Upon consenting to be part of the research, the students were asked through paper/pen interview and google meet about the challenges they were facing in this new normal mode of delivery. After the interview, they were asked to answer the Survey on Teachers' Engagement and Communication Skills to give we baseline data before the program implementation.

\subsection{Data Analysis}


The quantitative data from the pre- intervention and post- intervention survey of were statistical analyzed using Mean to describe the level of teachers' engagement/involvement with the learners. The t-test was also utilized to get the significant difference of both means. In addition, the qualitative data from the pre- intervention interview and post- intervention interview was also coded in the RQDA tool.

\section{RESULTS AND DISCUSSION}

\section{Pre- Intervention Survey on Teachers' Engagement on Students' Learning}

Data gathered after the first survey on the level of teachers' engagement manifested in the manner the students' perceived the way their teachers communicated with them as well as the teachers' attitude is shown in Table 1. Result showed that the level of engagement between teachers and students is perceived by students to be on the average. Between teachers' attitude and communication skills, it is the teachers' attitude that was evaluated by students to be higher in impact to them compared to their teachers' communication abilities.

Table 1. Summary of Pre- Evaluation of Teachers' Engagement and Communication Skills

\begin{tabular}{lll}
\hline \multicolumn{1}{c}{ Item } & Mean & Qualitative Description \\
\hline COMMUNICATION SKILLS & $\mathbf{2 . 8 2}$ & Average \\
\hline I feel energized. & 2.51 & Average \\
I feel motivated to continue with my studies. & 2.62 & Average \\
I feel valued and appreciated. & 2.4 & Low \\
I am more confident to answer my modules. & 2.59 & Average \\
I am clarified how to answer my modules. & 3.01 & Average \\
I feel understood and accepted. & 3.46 & Average \\
My ability to perform my tasks was increased. & 2.46 & Low \\
I feel satisfied. & 3.34 & Average \\
I am guided towards positive direction for personal & 3.02 & Average \\
growth. & $\mathbf{3 . 6 3}$ & High \\
\hline ATTITUDE & 3.61 & High \\
\hline They are fair in dealing with us as students. & 3.64 & High \\
Do not discriminate. & 3.71 & High \\
Are affectionate and warm. & 3.51 & High \\
Provides comfort and improves my mood. & 3.56 & High \\
Presents information in a way that is easy to understand. & 3.46 & High \\
Are sensitive to my needs. & 3.98 & High \\
Cares about my academic needs. & 3.89 & High \\
Cares about my social needs. & 3.79 & High \\
Treats me as an important part of the class. & 3.8 & High \\
Encourages me to speak my mind. & 3.01 & High \\
Takes time to assist me when I need help. & $\mathbf{3 . 4 5}$ & AVERAGE \\
\hline Total & &
\end{tabular}

In the area of Communication skills of teachers, students evaluated it as average. Among all the items, it is only on two aspects that they find their teachers as lacking. Evidently, the students felt that though their teachers are always there whenever they need help, still they would want the connection to be stronger and more intimate $(\mathrm{x}=2.40)$.

On the aspect of being valued and appreciated, students felt that teachers are lacking in terms of showing importance to them and that they need to appreciate their students' performance more. Data further revealed that students also felt that their abilities to perform the tasks expected of them needs to be addressed as it is in the low level $(\mathrm{x}=2.46)$.

\section{Post-Intervention Survey on Teachers' Engagement on Students' Learning}


Table 2 presents the post-evaluation survey result on student-teacher engagement. It was based on the responses of students after the OCEANS 13 intervention was conducted by the senior high school teachers of Federico Yap National High School.

In terms of communication skills, the teachers' manner of interaction with them was given a very high evaluation by the respondents except on the area where they are expected to guide the students towards a positive direction for personal growth. Though it was lower than the other items, still it is on the high level. Also, the students gave a very high evaluation of the attitude of the teachers both in online and face to face interaction. However, they expressed desire for improvement on the aspects of being affectionate and warm, providing comfort, and being more sensitive to the needs of the learners. Overall, the evaluation for the teacher's engagement in the learning of the respondents is very high $(\mathrm{x}=4.65)$.

\section{Difference Between the Pre - Intervention and Post- Intervention Survey}

Computing for the difference between the mean scores of the pretest and post test results, Table 3 presents that the difference between the two means is significant even at the 0.01 level $(p=0.000345, p<$ .01 ). This signifies that the intervention program, the OCEANS 13 , is very effective as it was able to change significantly the perception of the students on the treatment of their teachers toward them. Their responses also indicate that they are more driven to continue their education as they are more confident in dealing with their school work. In addition, because their academic needs are met, they could also focus on their personal growth and development.

Table 2. Summary of the Post- Evaluation of Teachers' Engagement and Communication Skills

\begin{tabular}{lll}
\hline \multicolumn{1}{c}{ Item } & Mean & $\begin{array}{l}\text { Qualitative } \\
\text { Description }\end{array}$ \\
\hline COMMUNICATION SKILLS & $\mathbf{4 . 6 5}$ & Very High \\
\hline I feel energized. & 4.56 & Very High \\
I feel motivated to continue with my studies. & 4.79 & Very High \\
I feel valued and appreciated. & 4.67 & Very High \\
I am more confident to answer my modules. & 4.75 & Very High \\
I am clarified how to answer my modules. & 4.72 & Very High \\
I feel understood and accepted. & 4.6 & Very High \\
My ability to perform my tasks was increased. & 4.68 & Very High \\
I feel satisfied. & 4.66 & Very High \\
I am guided towards positive direction for personal growth. & 4.43 & Very High \\
\hline ATTITUDE & $\mathbf{4 . 6 5}$ & Very High \\
\hline They are fair in dealing with us as students. & 4.67 & Very High \\
Do not discriminate. & 4.71 & Very High \\
Are affectionate and warm. & 4.49 & Very High \\
Provides comfort and improves my mood. & 4.43 & Very High \\
Presents information in a way that is easy to understand. & 4.51 & Very High \\
Are sensitive to my needs. & 4.46 & Very High \\
Cares about my academic needs. & 4.65 & Very High \\
Cares about my social needs. & 4.71 & Very High \\
Treats me as an important part of the class. & 4.89 & Very High \\
Encourages me to speak my mind. & 4.78 & Very High \\
Takes time to assist me when I need help. & 4.9 & Very High \\
\hline Total & $\mathbf{4 . 6 5}$ & Very High \\
\hline & & \\
\hline & &
\end{tabular}


Table 3. t-Test Results Comparing Pre and Post Surveys on Teachers' Engagement in Students' Learning

\begin{tabular}{lcrrrr}
\hline & $\mathrm{n}$ & Mean & \multicolumn{1}{c}{ SD } & df & $\mathrm{p}$ \\
\hline Pre-Test & 73 & 3.45 & 0.139 & 72 & 0.00035 \\
\hline Post-Test & 73 & 3.45 & 0.11 & & \\
\hline$* *$ The result is significant at $p<.01$. & & & & & \\
\hline
\end{tabular}

As shown in Table 4, all the Grade 11 learners during the SY 2020-2021 passed their subjects and were promoted to Grade 12. This means that the OCEANS 13 was effective to the learners' performance especially to those who are at risk of failing.

Table 4. Learners' Status on the Second Quarter SY 2020-2021.

\begin{tabular}{cccccccc}
\hline & \multicolumn{3}{c}{ Complete } & \multicolumn{3}{c}{ Incomplete } \\
\hline Track & M & F & Total & M & F & Total \\
\hline
\end{tabular}

Technical Vocational Livelihood Bread and Pastry

Production, Food and Beverage Services, Hairdressing

Technical Vocational Livelihood Electrical Installation and Maintenance

Technical Vocational Livelihood Shielded Metal Arc Welding

Technical Vocational Livelihood Computer Hardware Servicing

Academic Track Accountancy, Business and Management

Total

\begin{tabular}{cccccc}
7 & 53 & 60 & 0 & 0 & 0 \\
28 & 10 & 38 & 0 & 0 & 0 \\
41 & 3 & 44 & 0 & 0 & 0 \\
20 & 5 & 25 & 0 & 0 & 0 \\
7 & 21 & 28 & 0 & 0 & 0 \\
$\mathbf{1 0 3}$ & $\mathbf{9 2}$ & $\mathbf{1 9 5}$ & $\mathbf{0}$ & $\mathbf{0}$ & $\mathbf{0}$ \\
\hline
\end{tabular}

Through the conduct of OCEANS 13 program, the learners are motivated to learn. Despite the challenges of this pandemic, they still managed to continue their studies.

"Mas ganahan ko mupadayon ug answer. Gaan kaayu sa feeling nang gina laanan kag time sa teachers." [I was motivated to continue answering the modules. It is so heart-warming that the teachers spent time for me.] [42385:42481]

"In my experience when struggles challenge me, I will chat her and she will give me an advice that is very inspirational and motivational. Every time we are chatting with each other she will send a message that can make my heart fueled and energized. Every time I read her message makes me happy and it pushes me to strive harder and even stronger. Her advices mean to me so much. In my whole life in studying, I can say that it's rare to have a teacher to motivate you and help you. And I am blessed to have a teacher like her. I really wish that one day she will be a role model to other teacher to do the same and stand not just a source of knowledge but also a source of hope." [52491:53168] 
"By encouraging us to continue our journey and by believing our abilities that we can do it and graduate. By reminding us that education is important in our life." [47940:48103]

"They appreciate us, praising us, when we get an achievement (big or small). And lastly, they didn't stop from reminding us that every hardwork will be paid off someday." [46312:46864]

The learners felt their teachers helped them in answering the modules. The teachers also understood the learners who submitted their answer sheets beyond the schedule.

"The teachers really took care and love their students very well because they always listen to students when students want to ask them some questions regarding on the modules." [44440:44615]

Furthermore, the teachers are very concerned with the learners' academic performance. They communicated to them about their lacking requirements, modules that are unanswered and their grades.

"They are so good and they always remind us about our grades. They send a private message and they mentioned us in the group chat so that we know that we have not yet passed the requirements. " [56190:56380]

Thus, this act of communicating with the learners can help them especially those at risk of learning to improve their performance.

"These simple visitations, chatting us if we are still alright, reminding us of our activities, encouraging us to still go on and fight, these things are really heartwarming actions that somehow eased up our stress and worries we, students, are currently have. " [29049:29309]

\section{CONCLUSION}

Based from the results of the intervention conducted, we recommend to continue implementing the OCEANS 13 Program in the school not just only in the Senior High School but in the Junior High School as well.

As teachers we are concerned about the performance of our students especially during this pandemic where they cannot actively question their teachers whenever they did not understand the lessons. Moreover, the modular distance learning mode of delivery made it difficult for students to be properly guided in their academic endeavors. Since 2020, at the onset of COVID 19 pandemic, the turnover of modules and even the quality of student outputs are far from the ideal. Students evidently are suffering but they have to make do with whatever is available and allowed as health is more important.

As the first year ushered in the second year of the pandemic, teachers are now resolute on improving the delivery of learning, exploring and trying all alternatives just to make sure that students will not move to the next grade half-baked. Hence, Project OCEANS 13 was born.

Our efforts in the conduct of the OCEANS 13 were never in vain. We came to a realization point that as teachers, we would extend and expand the established "contact surface" with our learners. We should have a more intimate connection with them by the use of different communication channels as expressed in the thrust of OCEANS 13.

This research was only limited to the modular instruction mode of delivery of learning during the pandemic. Hence, the researchers suggest that this intervention will be studied to other delivery of learning like online teaching, tutorial and face-to-face learning. 


\section{REFERENCES}

Asrar, Z. et al. (2018). The Impact of Communication Between Teachers and Students: A Case Study of the Faculty of Management Sciences, University of Karachi, Pakistan. European Scientific Journal June 2018 edition Vol.14, No.16 ISSN: 1857 - 7881. Doi:10.19044/esj.2018.v14n16p32

Baruch Alona Forkosh, Arnon Hershkovitz, \& Rebecca P. Ang. (2015). "Teacher-student Relationship and SNSmediated Communication: Perceptions of both Role-players." Interdisciplinary Journal of e-Skills and Lifelong Learning.

Garcia, J. (2014). Teacher and parent beliefs and expectations of parental involvement and how it relates to student academic achievement. Texas State University.

Henderson, A. T., Mapp, K. L., Johnson, V. R., \& Davies, D. (2007). Beyond the bake sale: The essential guide to family-school partnerships. New York, NY: The New Press.

Khan Alamgir, Dr Salahuddin Khan, Syed Zia-Ul-Islam, \& Manzoor Khan (2017). "Communication Skills of a Teacher and Its Role in the Development of the Students' Academic Success." Journal of Education and Practice.

Khan, A., Khan, S., Zia-Ul-Islam, S., \& Khan, M. (2017). Communication Skills of a Teacher and Its Role in the Development of the Students' Academic Success. Journal of Education and Practice, 8(1), 18-21.

Lee, Q.A., \& Yuen, M. (2019). The role of teacher care in determining academic success of community college students: A case study from Hongkong. Pastoral Care in Education, 37 (2), 94-107.

Lei, H., Cui, Y., \& Chiu, M. M. (2018). The Relationship between Teacher Support and Students 'Academic Emotions: A Meta-Analysis. Frontiers in Psychology, 8. doi:10.3389/fpsyg.2017.02288

Noddings, N. (2006). Educational leaders as caring teachers. School leadership and management, 26(4), 339-345.

Paschal, M. J., \& Mkulu, D. G. (2021, September 6). The Contribution of Private Sector in the provision of Higher Education in Tanzania: Growth and Challenges. https://doi.org/10.22161/jhed.2.3.2

Reeve, J., \& Shin, S.H. (2020). How teachers can support students' agentic engagement. Theory into Parctice, 59 (2), $150-161$.

Richmond Virginia, P. (1990). "communication in the class room: power and motivation." communication education. 